\title{
Productive and metabolic response to two levels of corn silage supplementation in grazing dairy cows in early lactation during autumn
}

\author{
Álvaro Morales ${ }^{1}$, Daniela Grob ${ }^{1}$, Oscar Balocchi² ${ }^{2}$ and Rubén Pulido ${ }^{*}$
}

Corn (Zea mays L.) silage (CS) is a nutritious food that can be used as a supplement in dairy cows. The aim of this study was to determine the effect of supplementation with two amounts of CS on milk production and composition, live weight and body condition, as well as on some blood indicators for energy and protein metabolism on dairy cows in early lactation and grazing low mass pasture during autumn. The study was carried out in 40 Holstein Friesian cows over $57 \mathrm{~d}$. Prior to experimental treatment, milk production and days of lactation averaged $24.1 \pm 2.8 \mathrm{~kg} \mathrm{~d}^{-1}$ and $62 \pm 14 \mathrm{~d}$, respectively. The dietary treatments consisted of two levels of supplementation with CS; 4.5 and $9 \mathrm{~kg} \mathrm{DM} \mathrm{cow}^{-1} \mathrm{~d}^{-1}$ (treatments LCS and HCS, respectively). Additionally, all the cows received a pasture allowance of 21 and $3 \mathrm{~kg} \mathrm{DM} \mathrm{cow}^{-1} \mathrm{~d}^{-1}$ of concentrate. Milk composition was determined using infrared spectrophotometry, while blood indicators were obtained using an autoanalyzer. There were not differences between treatments regarding milk production or composition, total DM or energy intake. Herbage and protein intake was higher for LCS treatment $(\mathrm{P}<0.001)$. Increasing supplementation decreased $(\mathrm{P}<0.001)$ daily weight gain but did not affect body condition. Plasma concentrations of $\beta O H$-butyrate were lower $(\mathrm{P}=0.038)$ for the LCS treatment; while urea concentrations were higher $(\mathrm{P}=0.003)$, with no differences for non-esterified fatty acids $(\mathrm{NEFA})$ concentrations. Supplementation with $4.5 \mathrm{~kg} \mathrm{~d}^{-1}$ of CS was sufficient to meet the production requirements of the cows.

Key words: Autumn pasture, corn silage, dairy cows, grazing, low herbage mass pasture.

\section{INTRODUCTION}

In temperate regions, milk production systems base their diet on pastures used as grazing fields, which is the cheapest available source of nutrients (Balocchi et al., 2002). Therefore, to reduce production costs it is necessary to maximize the inclusion of grazing pasture in the annual diet of dairy cows, which could be achieved by extending the grazing season (Pérez-Prieto et al., 2011). However, nutrients intake from pasture diets alone generally is insufficient to meet requirements of high producing cows (Kolver and Muller, 1998), situation which is intensified in periods of low mass pastures as occurs during autumn due to weather conditions (rainfall $>50 \mathrm{~mm} \mathrm{mo}^{-1}$ and average daily temperature of $12{ }^{\circ} \mathrm{C}$ ) and seasonality of pasture species, which affect growth and nutritional quality of forage. These periods are characterized by low DM concentration, low herbage mass pasture, and low nonstructural carbohydrate (NSC) concentrations (< $17 \% \mathrm{DM}, \leq 1800 \mathrm{~kg} \mathrm{DM} \mathrm{ha}{ }^{-1}$ and $180-190 \mathrm{~g} \mathrm{~kg}^{-1} \mathrm{DM}$,

\footnotetext{
${ }^{1}$ Universidad Austral de Chile, Facultad de Ciencias Veterinarias, Campus Isla Teja, Casilla 567, Valdivia, Chile.

*Corresponding author (rpulido@uach.cl).

${ }^{2}$ Universidad Austral de Chile, Facultad de Ciencias Agrarias, Campus Isla Teja, Casilla 567, Valdivia, Chile.

Received: 16 September 2013.

Accepted: 11 March 2014.
}

doi:10.4067/S0718-58392014000200012 respectively), but with high crude protein (CP) content (200 a $300 \mathrm{~g} \mathrm{~kg}^{-1} \mathrm{DM}$ ) (Pulido et al., 2010). As a result of autumn grazing conditions, main factors limiting milk production are low DM intake (6 to $9 \mathrm{~kg} \mathrm{DM} \mathrm{cow}^{-1}$ $\left.\mathrm{d}^{-1}\right)$ and energy intake, and a lack of synchrony - when releasing nutrients to the rumen - between degradable CP and energy supply of the herbage (Ruiz-Albarrán et al., 2012; Sotelo et al., 2012). Therefore, it is necessary to use supplementary food that ensures a stable supply in quantity and quality of nutrients in the rumen, balances pastures deficiencies, and increases DM intake, nutrients intake and milk production (Bargo et al., 2003).

Although grass silage is the most widely used supplement in this period, its quality is highly variable, corn (Zea mays L.) being a possible alternative to be used. Corn silage has been widely used in confinement systems in USA and Europe; however, in countries with grazing systems (Australia, France, New Zealand, and south of South America) there is an increasing recent interest in its use as a supplement to extend the grazing season (Stockdale, 1995; Pérez-Prieto et al., 2011). Corn silage is a highly nutritious food that can be used to complement autumn herbage characteristics and presents competitive yield and cost compared to other crops (Hazard et al., 2001). Pérez-Prieto et al. (2011) supplemented with 0 and $8 \mathrm{~kg} \mathrm{DM}$ of corn silage to latelactation dairy cows grazing a pasture allowances of 18 and $30 \mathrm{~kg} \mathrm{DM} \operatorname{cow}^{-1} \mathrm{~d}^{-1}$, reported a significant increase 
by supplementation $\left(5.2 \mathrm{~kg}\right.$ milk $\left.\mathrm{cow}^{-1} \mathrm{~d}^{-1}\right)$ and by pasture allowances $\left(1.4 \mathrm{~kg}\right.$ milk cow $\left.{ }^{-1} \mathrm{~d}^{-1}\right)$; they concluded that under those conditions unsupplemented grazing cows are unable to meet their requirements for production. In the same season, Ruiz-Albarrán et al. (2011) have shown that when grazing dairy cows are supplemented with 6.2 $\mathrm{kg}$ DM cow ${ }^{-1} \mathrm{~d}^{-1}$ corn silage during autumn, compared to grass silage (GS), milk production $\left(2.3 \mathrm{~kg} \mathrm{cow}^{-1}\right)$, protein concentrations and food intake increased $(2.2 \mathrm{~kg})$ and milk urea and plasma urea concentrations decreased compared to GS (P<0.001).

Complementing productive assessments, the use of metabolic profiling allows us to assess the adequacy of main metabolic pathways related to energy, protein and minerals; thus providing information related to nutrition and animal health (Wittwer, 2012) and hence, providing a support to the design and evaluation of strategies aimed at optimizing productive and reproductive potential of cows (Bobe et al., 2004).

Although there is information about the effect of supplementation with corn silage in dairy cows, these studies have been conducted in confinement conditions, accompanied by other types of supplements and at different stages of lactation or seasons, so it is necessary to obtain more information about the proper amount of corn silage supplementation and its effect on production and metabolic parameters of grazing dairy cows in early lactation on autumn pasture. The aim of this study was to determine the effect of supplementation with two increasing amounts of corn silage on productivity, milk composition, live weight, and body condition scores as well as on levels of some blood indicators of energy and protein metabolism of autumn-calving dairy cows in early lactation grazing low mass pasture in southern Chile.

\section{MATERIALS AND METHODS}

\section{Experimental site, animals and treatments}

The experiment was conducted at the Agropecuarian Austral Research Station of the Universidad Austral de Chile (UACh, 3947' S, 7314' W, 12 m a.s.1.), Valdivia, Chile. The soil type has been classified as a medial, mesic, typic Hapludand, series Valdivia of flat topography (Soil Survey Staff, 1992). The experiment lasted 57 d and was conducted in autumn between April and June 2012.

Forty multiparous 'Holstein Friesian' dairy cows from the University dairy herd (milk yield $24.1 \pm 2.8 \mathrm{~kg} \mathrm{~d}^{-1}$; parity $3.5 \pm 1.6$; days in milk $62.7 \pm 14$, and body weight $538 \pm 46 \mathrm{~kg}$ ) were grouped according to milk yield, parity, days in milk, and body weight. They were randomly assigned to two dietary treatments with corn silage supplementation: $4.5 \mathrm{~kg} \mathrm{DM} \mathrm{cow}{ }^{-1} \mathrm{~d}^{-1}$ (low corn silage, LCS) and $9.0 \mathrm{~kg} \mathrm{DM} \mathrm{cow}^{-1} \mathrm{~d}^{-1}$ (high corn silage, HCS). A control group was not included to avoid negative impact in the animal welfare and profitability of the farm due to an insufficient DM intake; therefore, two contrasting amounts of corn silage were selected. All of the cows received a pasture allowance above ground level of $21 \mathrm{~kg}$ DM cow ${ }^{-1} \mathrm{~d}^{-1}$ and $3 \mathrm{~kg} \mathrm{DM}$ concentrate $\operatorname{cow}^{-1} \mathrm{~d}^{-1}$. The base concentrate comprising (\% on DM basis) 49.3 corn, 11.5 soybean meal, 30.0 sugar beet pulp, 4.6 beet molasses, and 4.5 mineral mixture (Suralim Tipo, IANSAGRO, Temuco, Chile), was offered equally into each milking.

\section{Grazing and feeding management}

Grazing took place on a 10.6 ha ryegrass (Lolium perenne L.) dominant pasture, with each treatment herd grazing at the same paddock, but separated by an electric fence according to the correspondent corn silage supplementation. All animals were given access to new pasture after each milking under a rotational grazing system, with two rotations over the duration of this study.

To deliver the pasture allowance, pre-grazing compressed sward height was measured daily, using a rising plate meter (Filip's folding plate pasture meter, Jenquip, Feilding, New Zealand), taking 100 measurements randomly walking the paddocks in "W" pattern. Then the grazing area was calculated transforming the compressed sward height in $\mathrm{kg} \mathrm{DM} \mathrm{ha-1}$ using a linear regression equation developed for autumn (Canseco et al., 2009). The same method was used to evaluate the postgrazing residual.

Corn silage was made in the farm giving a fermentation time of $20 \mathrm{~d}$ before being used; the high content of DM in pre-ensiling ( $>30 \%$ ) allows us to have corn silage at the beginning of autumn season. It was offered in the pre-milking waiting yard using headlocks, thus avoiding competitiveness among animals, providing $60 \%$ of the ration after the morning milking and the remaining before the afternoon milking in order to facilitate the labor in the dairy and to allow the cows enough time to eat the supplement.

A mineral mix (Anasal Alta Producción, ANASAC, Temuco, Chile: Ca 14.0\%, P 10.0\%, Mg 6.0\%, Na 4.0\%, $\mathrm{S} 0.2 \%, 5000 \mathrm{mg} \mathrm{Zn} \mathrm{kg}{ }^{-1}, 1500 \mathrm{mg} \mathrm{Cu} \mathrm{kg}{ }^{-1}, 200 \mathrm{mg} \mathrm{I} \mathrm{kg}^{-1}$, $20 \mathrm{mg} \mathrm{Co} \mathrm{kg}{ }^{-1}, 14 \mathrm{mg} \mathrm{Se} \mathrm{kg}^{-1}$ ) was offered at free access in containers located prior to milking parlor. Water was offered ad libitum in the paddocks and in the pre-milking waiting yard.

Corn silage intake was calculated by determining the difference between weight of the offering and weight of silage rejected by the animals. Herbage DM intake was estimated indirectly from animal performance results (Baker, 1982) as follows:

Herbage DM intake $\left(\mathrm{kg} \mathrm{d}^{-1}\right)=\mathrm{ME}_{\mathrm{m}}+\mathrm{ME}_{\mathrm{ml}}+\mathrm{ME}_{\mathrm{lw}}+$ $\mathrm{ME}_{\mathrm{g}}-$ Conc $\mathrm{ME}-\mathrm{Cs} \mathrm{ME} /$ Herbage $\mathrm{ME}$

where $\mathrm{ME}_{\mathrm{m}}, \mathrm{ME}_{\mathrm{ml}}, \mathrm{ME}_{\mathrm{lw}}$, and $\mathrm{ME}_{\mathrm{g}}$ are estimated metabolizable energy (ME) requirements for maintenance, milk yield, live-weight change and gestation, respectively (AFRC, 1993); Conc ME and Cs ME represent ME supplied by the concentrate and supplemented corn silage, and Herbage ME is the estimated ME concentration of 
herbage samples.

\section{Experimental procedures and samplings}

Once a week, samples of the pasture consumed were obtained by cutting at the approximate height at which cows grazed. Three times during the study, samples of corn silage and concentrate were collected for chemical analyses. Dry matter content was determined by means of an air oven at 60 ${ }^{\circ} \mathrm{C}$ for $48 \mathrm{~h}$, ash by calcination in an oven at $550-600{ }^{\circ} \mathrm{C}$ for $5 \mathrm{~h}$, and ether extract (EE) and acid detergent fiber (ADF) by the AOAC procedure (AOAC, 1996), neutral detergent fiber (NDF) according to Van Soest et al. (1991). Crude protein (CP) was determined using LECO technology (AOAC, 2005), soluble protein (SP) and soluble carbohydrates (SC) were determined by Near Infrared Reflectance Spectroscopy (NIRS), $\mathrm{pH}$ and ammonia nitrogen $\left(\mathrm{NH}_{3}-\mathrm{N}\right)$ by AOAC (1996). Pasture, corn silage and concentrate ME values were estimated by regression using a " $D$ " value (g digestible organic matter $\left.\mathrm{g}^{-1} \mathrm{DM} \times 100\right)$ (Garrido and Mann, 1981), determined in vitro (Tilley and Terry, 1963) according to Goering and Van Soest (1972).

Animals were daily automatically weighed and body condition score (BCS) was recorded weekly using a fivepoint scale (Ferguson et al., 1994). Cows were milked at 07:00 and 15:30 h and milk yield was electronically measured at each milking time, whereas the milk persistency, body weight, and body condition score changes were determined for each animal as the slope from a linear regression during the trial. Representative subsamples were collected weekly at AM and PM milking for milk fat, milk total protein, and urea analyses by infrared spectroscopy (Foss 4300 MilkoScan, FOSS Electric, Hillerød, Denmark).

Four coccygeal blood samples were obtained following the afternoon milking (17:00 h). Blood was deposited into 5 $\mathrm{mL}$ labeled tubes containing sodium heparin anticoagulant. Plasma was separated after centrifugation at $800 \mathrm{~g}$ for 10 min, aliquoted in $1.5 \mathrm{~mL}$ microtubes and frozen at $-20{ }^{\circ} \mathrm{C}$ until analyses.After the experimental phase, plasma samples were thawed and concentrations of beta-hydroxybutyrate ( $\beta \mathrm{OH}$-butyrate) determined by NAD-dependent enzymatic UV method (Ranbut, Randox Laboratories, Crumlin, UK), non-esterified fatty acids (NEFA) using enzymatic colorimetric method (NEFA assay, Randox Laboratories) and urea by GLDH UV (glutamate dehydrogenase-) by kinetic method (UREA liquiUV, HUMAN Gesellschaft für Biochemica und Diagnostica mbH, Wiesbaden, Germany) using an autoanalyzer (Metrolab 2300, Wiener Lab., Rosario, Argentina).

In the last week of the study, spot urine samples were collected when cows urinated spontaneously or by vulva stimulation $(08: 00 \mathrm{~h})$ for determination of ketone bodies (acetoacetate and acetone) for Rothera test, to be contrasted with cows blood concentrations of $\beta \mathrm{OH}-$ butyrate concordant with subclinical ketosis values $(\geq 1.2$ mmol L ${ }^{-1}$ ) (Geishauser et al., 1998). Samples of $50 \mathrm{~mL}$ were obtained and then transferred in tubes of $5 \mathrm{~mL}$ with sulfuric acid to be frozen at $-20{ }^{\circ} \mathrm{C}$ until analyses. After thawing, samples were centrifuged and the supernatant transferred to $1.5 \mathrm{~mL}$ microtubes. Later, $1 \mathrm{~mL}$ urine sample was added to a test tube with Rothera reagent (sodium nitroprusside) and the reaction was qualified according to the magnitude of the color change (no change to deep violet), $\mathrm{N}=$ negative, $\mathrm{L}=$ light, $\mathrm{M}=$ moderate, I = intense (Geishauser et al., 1998). Weather data for the experimental period were consulted in the reports of UACh meteorological stations (Boletín Climático, 2012; Estación Meteorológica UACh, 2013).

\section{Statistical analyses}

The experimental design was completely randomized, where the animals were on the same treatment throughout the experiment. The pasture management, chemical composition, estimated food intake, milk production and composition, live weight and body condition score values were presented as mean $(\overline{\mathrm{X}} \pm \mathrm{SD})$ and evaluated with a one way ANOVA. The normality of data was established using the Shapiro-Wilk test and homoscedasticity through the Levene test. Comparison of blood metabolites was evaluated using a parametric ANOVA for repeated measures. The interaction between treatment $\times$ week was analyzed for blood metabolites according to the following statistical model:

$$
\mathrm{Y}_{\mathrm{ijk}}=\mu+\mathrm{T}_{\mathrm{i}}+\mathrm{W}_{\mathrm{j}}+\mathrm{TW}_{\mathrm{ij}}+\mathrm{C}_{\mathrm{k}}+\mathrm{e}_{\mathrm{ijk}}
$$

where $Y_{i j k}$ is dependent variable, $\mu$ is intercept, $T_{i}$ is fixed effect of the $i^{\text {th }}$ treatment, $W_{j}$ is fixed effect of the $j$ week; $T S_{i j}$ is fixed effect of the interaction between the $i^{\text {th }}$ treatment and the $j$ week; $C_{k}$ is effect of the $k$ cow and $e_{i j k}$ is residual error. Blood metabolites were adjusted by body condition score as a covariate, but corrected values were not significant, therefore were not included. The comparison of differences between treatments was done using Tukey test. The statistical analysis was done using the statistical software Minitab 16.1.0 (Minitab Inc., State College, Pennsylvania, USA) with a significance level of 95\% $(\mathrm{P}<0.05)$.

\section{RESULTS}

\section{Weather conditions}

During the experiment, average daily temperature was 9.6 ${ }^{\circ} \mathrm{C}$ and average maximum and minimum were $12.3{ }^{\circ} \mathrm{C}$ and $6.5^{\circ} \mathrm{C}$, respectively. Mean daily rainfall was $10.4 \mathrm{~mm}(34$ rainy days and $450.4 \mathrm{~mm}$ during experimental period). During May the average daily precipitation and maximum and minimum temperature were above historical records in $25 \mathrm{~mm}, 0.4^{\circ} \mathrm{C}$, and $0.8^{\circ} \mathrm{C}$, respectively, and for June these values were under historical records in $25 \mathrm{~mm}$; 0.1 ${ }^{\circ} \mathrm{C}$ and $0.4{ }^{\circ} \mathrm{C}$, respectively.

\section{Sward and supplement characteristics}

Results for pasture management variables are shown in Table 1. During the study, the offered daily pasture 
allowance was $21 \mathrm{~kg} \mathrm{cow}^{-1} \mathrm{~d}^{-1}$ for both treatments. No significant differences were found between treatments for any of the variables analyzed, but a decrease of pregrazing herbage mass and herbage intake along the trial was observed (average $3.069 \mathrm{~kg} \mathrm{DM} \mathrm{ha}^{-1}$ and $9.22 \mathrm{~kg}$ DM cow $^{-1} \mathrm{~d}^{-1}$ for May vs. $2.051 \mathrm{~kg} \mathrm{DM} \mathrm{ha}{ }^{-1}$ and $6.03 \mathrm{~kg}$ DM $\operatorname{cow}^{-1} \mathrm{~d}^{-1}$ for June, respectively). Nutritional characteristics of the herbage and supplementary food are presented in Table 2. No significant differences were found in

Table 1. Pasture management parameters during the experiment, in autumn-grazing dairy cows in early lactation and fed on low (LCS) and high corn silage supplementation (HCS).

\begin{tabular}{|c|c|c|c|}
\hline \multirow[b]{2}{*}{ Pasture management } & LCS & HCS & \multirow{2}{*}{$\begin{array}{l}\text { Signi- } \\
\text { ficance }\end{array}$} \\
\hline & $\bar{X} \pm S D$ & $\bar{X} \pm S D$ & \\
\hline Pasture allowance, $\mathrm{kg} \mathrm{DM} \mathrm{cow}{ }^{-1} \mathrm{~d}^{-1}$ & 21 & 21 & \\
\hline Area, $\mathrm{m}^{2}$ cow $^{-1} \mathrm{~d}^{-1}$ & $83.1 \pm 24.9$ & $82.0 \pm 22.1$ & 0.985 \\
\hline Pre-grazing herbage mass, $\mathrm{kg} \mathrm{DM} \mathrm{ha}^{-1(1)}$ & $2.683 \pm 575.6$ & $2.691 \pm 544.4$ & 0.980 \\
\hline Sward height pre-grazing, $\mathrm{cm}^{(2)}$ & $9.72 \pm 2.3$ & $9.75 \pm 2.2$ & 0.980 \\
\hline Post-grazing herbage mass, $\mathrm{kg} \mathrm{DM} \mathrm{ha-1(1)}$ & $1.570 \pm 204.1$ & $1.616 \pm 200.6$ & 0.633 \\
\hline Sward height post-grazing, $\mathrm{cm}^{(2)}$ & $5.09 \pm 0.85$ & $5.28 \pm 0.83$ & 0.633 \\
\hline Proportion of pasture harvested, $\%$ & 41.4 & 39.7 & 0.374 \\
\hline
\end{tabular}

${ }^{(1)}$ Equation to estimate the herbage mass: $\mathrm{Y}=120 \mathrm{X}+350\left(\mathrm{R}^{2}=0.74\right), \mathrm{Y}$ $=$ Herbage mass $\left(\mathrm{kg} \mathrm{DM} \mathrm{ha}^{-1}\right), \mathrm{X}=$ compressed height measured with the plate (Canseco et al., 2009).

${ }^{(2)}$ It corresponds to the compressed height measured with the rising plate meter.

Table 2. Chemical composition of food used in the experiment.

\begin{tabular}{|c|c|c|c|c|c|c|c|c|c|}
\hline & \multicolumn{4}{|c|}{ Pasture } & & \multicolumn{2}{|c|}{ Corn silage } & \multicolumn{2}{|c|}{ Concentrate $^{(1)}$} \\
\hline & \multicolumn{2}{|c|}{ LCS } & \multicolumn{2}{|c|}{ HCS } & \multirow[b]{2}{*}{ Significance } & \multirow{2}{*}{\multicolumn{2}{|c|}{$\overline{\mathrm{X}} \pm \mathrm{SD}$}} & \multirow{2}{*}{\multicolumn{2}{|c|}{$\bar{X} \pm \mathrm{SD}$}} \\
\hline & \multicolumn{2}{|c|}{$\overline{\mathrm{X}} \pm \mathrm{SD}$} & \multicolumn{2}{|c|}{$\overline{\mathrm{X}} \pm \mathrm{SD}$} & & & & & \\
\hline Number of samples & & & & & & \multicolumn{2}{|c|}{3} & \multicolumn{2}{|c|}{3} \\
\hline $\mathrm{DM}^{(2)}$ & 12.7 & 2.56 & 12.7 & 2.62 & 0.995 & 36.0 & 3.34 & 87.4 & 0.30 \\
\hline Ash & 9.7 & 1.07 & 9.6 & 0.95 & 0.811 & 4.6 & 0.36 & 4.5 & 0.20 \\
\hline $\mathrm{CP}$ & 24.6 & 2.53 & 25.2 & 3.46 & 0.721 & 9.5 & 0.50 & 15.2 & 0.10 \\
\hline $\mathrm{EE}$ & 2.2 & 0.37 & 2.3 & 0.49 & 0.640 & 2.9 & 0.29 & 3.0 & 0.55 \\
\hline ME, Mcal kg-1 DM & 2.84 & 0.04 & 2.84 & 0.08 & 0.952 & 2.74 & 0.01 & 3.14 & 0.06 \\
\hline $\mathrm{NDF}$ & 53.9 & 3.24 & 54.0 & 4.12 & 0.989 & 47.2 & 0.78 & 22.0 & 2.35 \\
\hline $\mathrm{ADF}$ & 21.3 & 0.60 & 21.2 & 1.18 & 0.930 & 26.3 & 0.51 & 10.8 & 0.01 \\
\hline $\mathrm{SC}$ & 7.6 & 1.33 & 7.4 & 1.47 & 0.756 & - & - & - & - \\
\hline $\mathrm{NSC}^{(3)}$ & 9.6 & 6.36 & 9.0 & 7.60 & 0.875 & 35.8 & 0.60 & 55.3 & 1.79 \\
\hline SP & 8.4 & 1.84 & 8.42 & 1.68 & 0.983 & - & - & - & - \\
\hline "D" value & 78.83 & 1.50 & 78.81 & 2.40 & 0.980 & 75.9 & 0.35 & 87.6 & 1.85 \\
\hline $\mathrm{pH}$ & - & - & - & - & & 3.9 & 0.05 & - & - \\
\hline $\mathrm{N}-\mathrm{NH}_{3}, \%$ total $\mathrm{N}$ & - & - & - & - & & 5.25 & 0.61 & - & - \\
\hline
\end{tabular}

${ }^{(1)}$ Concentrate prepared especially for this experiment by IANSAGRO S.A.

${ }^{(2)}$ Data are presented as \% DM unless otherwise indicated.

DM: Dry matter; CP: crude protein; EE: ether extract; ME: metabolizable energy; NDF: neutral detergent fiber; ADF: acid detergent fiber; SC: soluble carbohydrates; NSC: nonstructural carbohydrates; SP: soluble protein; "D" value: DM in vitro digestibility; $\mathrm{N}-\mathrm{NH}_{3}$ : ammonia nitrogen; -: Values not determined.

${ }^{(3)} \mathrm{NSC}=100-(\operatorname{Ash}(\%)+\mathrm{CP}(\%)+\mathrm{EE}(\%)+\mathrm{NDF}(\%))$.

Table 3. Estimated intake and dietary proportion of concentrate, corn silage, pasture, total DM intake, protein, energy, neutral detergent fiber (NDF), in autumn-grazing dairy cows in early lactation and fed on low (LCS) and high corn silage supplementation (HCS).

\begin{tabular}{|c|c|c|c|c|c|c|}
\hline Estimated food intake & LCS & $\begin{array}{c}\text { Dietary } \\
\text { proportion }\end{array}$ & HCS & $\begin{array}{c}\text { Dietary } \\
\text { proportion }\end{array}$ & SD & Significance \\
\hline & & $\% \mathrm{DM}$ & & $\% \mathrm{DM}$ & & \\
\hline Concentrate, $\mathrm{kg} \mathrm{DM} \operatorname{cow}^{-1} \mathrm{~d}^{-1}$ & 3.0 & 20.12 & 3.0 & 19.73 & & \\
\hline Corn silage, $\mathrm{kg} \mathrm{DM} \mathrm{cow}^{-1} \mathrm{~d}^{-1}$ & $4.61 \mathrm{a}$ & 30.91 & $7.99 \mathrm{~b}$ & 52.56 & 0.41 & $<0.001$ \\
\hline Pasture, kg DM cow ${ }^{-1} \mathrm{~d}^{-1}$ & $7.29 \mathrm{a}$ & 48.89 & $4.22 \mathrm{~b}$ & 27.76 & 0.78 & $<0.001$ \\
\hline Total DM intake, $\mathrm{kg} \mathrm{DM} \mathrm{cow}^{-1} \mathrm{~d}^{-1}$ & 14.91 & 100 & 15.20 & 100 & 0.70 & 0.329 \\
\hline Protein intake, $\mathrm{g} \mathrm{cow}^{-1} \mathrm{~d}^{-1}$ & $2.689 \mathrm{a}$ & 18.03 & $2.279 b$ & 14.99 & 182.60 & $<0.001$ \\
\hline Energy intake, Mcal cow ${ }^{-1} \mathrm{~d}^{-1}$ & 42.78 & $2.86^{(1)}$ & 43.28 & $2.84^{(1)}$ & 2.00 & 0.557 \\
\hline NDF intake, g cow $^{-1} \mathrm{~d}^{-1}$ & 6.772 .9 & 45.42 & 6.712 .3 & 44.15 & 380.70 & 0.707 \\
\hline
\end{tabular}

Different letters in the row indicate significant differences according to one way ANOVA $(\mathrm{P}<0.05)$.

${ }^{(1)}$ Mcal EM kg-1 DM. 
Table 4. Milk production and composition, in autumn-grazing dairy cows in early lactation and fed on low (LCS) and high corn silage supplementation (HCS)

\begin{tabular}{|c|c|c|c|c|c|c|c|}
\hline \multirow{2}{*}{$\begin{array}{l}\text { Corn silage } \\
\text { supplementation }\end{array}$} & \multicolumn{3}{|c|}{ Milk production } & \multicolumn{4}{|c|}{ Milk composition } \\
\hline & Yield & Persistency & Fat & Protein & Fat & Protein & Urea \\
\hline & 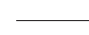 & - & 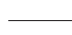 & - & 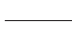 & - & $\mathrm{mmol} \mathrm{L}^{-1}$ \\
\hline LCS & 22.5 & -0.103 & 4.02 & 3.29 & 0.88 & 0.73 & 4.12 \\
\hline $\mathrm{HCS}$ & 22.6 & -0.101 & 3.97 & 3.32 & 0.88 & 0.73 & 3.97 \\
\hline SD & 3.55 & 0.07 & 0.86 & 0.038 & 0.19 & 0.11 & 1.17 \\
\hline Significance & 0.600 & 0.662 & 0.705 & 0.528 & 0.967 & 0.966 & 0.278 \\
\hline
\end{tabular}
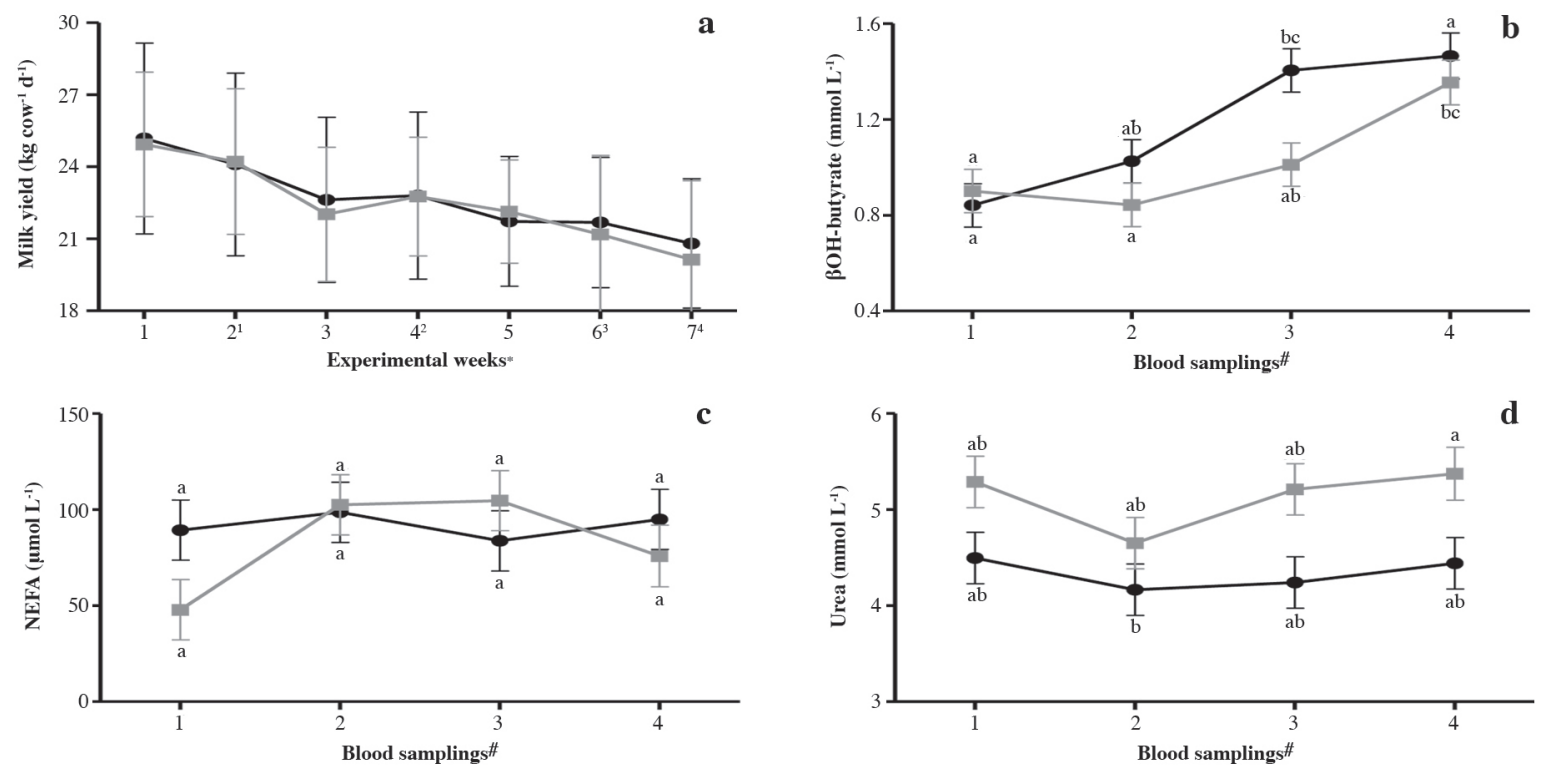

Figure 1. Weekly variation of milk production $(\overline{\mathrm{X}} \pm \mathrm{SD})$ and plasma concentrations of $\beta \mathrm{OH}-\mathrm{butyrate}, \mathrm{NEFA}$ and urea $(\overline{\mathrm{X}} \pm \mathrm{SEM})$, in autumngrazing dairy cows in early lactation and fed on low (LCS $\square$ ) and high corn silage supplementation (HCS •).

Different letters indicate significant differences between samplings according to Tukey's test $(\mathrm{P}<0.05)$.

"It corresponds to the seven experimental weeks from 9 May to 21 June 2012.

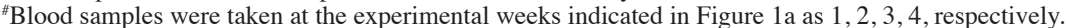

Table 5. Live weight and body condition score, in autumn-grazing dairy cows in early lactation and fed on low (LCS) and high corn silage supplementation (HCS).

\begin{tabular}{lccccc}
\hline & \multicolumn{2}{c}{$\begin{array}{c}\text { Live weight } \\
(\mathrm{LW})\end{array}$} & & \multicolumn{2}{c}{$\begin{array}{c}\text { Body condition } \\
\text { score (BCS) }\end{array}$} \\
\cline { 2 - 3 } \cline { 5 - 6 } $\begin{array}{l}\text { Corn silage } \\
\text { supplementation }\end{array}$ & $\begin{array}{c}\text { At experiment } \\
\text { start, } \mathrm{kg}\end{array}$ & $\begin{array}{c}\text { LW Gain } \\
\mathrm{kg} \mathrm{d}^{-1}\end{array}$ & & $\begin{array}{c}\text { At experiment } \\
\text { start }\end{array}$ & $\begin{array}{c}\text { Change of } \\
\text { BCS }\end{array}$ \\
\hline LCS & 538 & $0.149 \mathrm{a}$ & & 2.91 & 0.044 \\
HCS & 539 & $0.029 \mathrm{~b}$ & & 3.05 & 0.055 \\
SD & 46.63 & 0.51 & & 0.22 & 0.03 \\
Significance & 0.914 & $<0.001$ & & 0.065 & 0.313 \\
\hline
\end{tabular}

Different letters within a column indicate significant differences according to one way ANOVA $(\mathrm{P}<0.05)$.

the study $\left(0.12 \mathrm{~kg} \mathrm{~d}^{-1}\right)$. No differences were recorded in BCS change between treatments.

\section{Blood and urine metabolites}

The values of plasma concentrations of $\beta \mathrm{OH}$-butyrate, NEFA and urea are shown in Table 6. The LCS treatment had lower concentrations of $\beta \mathrm{OH}-$ butyrate $(\mathrm{P}=0.038)$, showing both treatments an increase in concentrations $>1.2 \mathrm{mmol} \mathrm{L}^{-1}$ in the last two samplings (Figure 1b).
Table 6. Blood plasma concentrations of $\beta \mathrm{OH}-b u t y r a t e$, nonesterified fatty acids (NEFA) and urea $(\bar{X} \pm$ SD), in autumn-grazing dairy cows in early lactation and fed on low (LCS) and high corn silage supplementation (HCS).

\begin{tabular}{lccc}
\hline Corn silage supplementation & $\beta O H$-butyrate & NEFA & Urea \\
\hline & $\mathrm{mmol} \mathrm{L}^{-1}$ & $\mu \mathrm{mol} \mathrm{L}^{-1}$ & $\mathrm{mmol} \mathrm{L}^{-1}$ \\
LCS & $1.03 \mathrm{a} \pm 0.42$ & $80.50 \pm 80.77$ & $5.03 \mathrm{a} \pm 1.05$ \\
HCS & $1.17 \mathrm{~b} \pm 0.50$ & $93.90 \pm 58.50$ & $4.43 \mathrm{~b} \pm 1.33$ \\
Significance & 0.038 & 0.244 & 0.003 \\
Interaction Supplementation $\times$ week & 0.099 & 0.135 & 0.838
\end{tabular}

Different letters within a column indicate significant differences according to repeated measured ANOVA $(\mathrm{P}<0.05)$.

No differences were found for NEFA concentrations ( $\mathrm{P}$ $=0.244$ ) nor among samplings (Figure 1c). The HCS treatment generated lower concentrations of urea during the experiment $(\mathrm{P}=0.003)$ (Figure 1d). There were no significant differences between treatments for the same sampling in any analyses.

During the last two samplings, ten cows of HCS treatment and four of the LCS presented $\beta \mathrm{OH}$-butyrate plasma concentrations above 1.2 , average 1.9 and 1.7 $\mathrm{mmol} \mathrm{L}^{-1}$ for HCS and LCS, respectively. Only one cow 
was positive to Rothera test (light reaction), being the only cow showing elevated values of plasma $\beta \mathrm{OH}$-butyrate in all samplings (averaging $1.8 \mathrm{mmol} \mathrm{L}^{-1}$ ).

\section{DISCUSSION}

\section{Weather conditions, sward and supplement characteristics}

The favorable weather conditions for the herbage growth during May, together with a long rest of the paddocks before starting the experiment, explain the high availability of pre-grazing herbage mass. Moreover, the botanical composition of the pasture, mainly composed by $L$. perenne $(95 \%)$, also explained the high herbage mass registered. Conversely, Schöbitz et al. (2013) reported herbage mass $<1700 \mathrm{~kg} \mathrm{DM}$ and an average herbage intake of $7.5 \mathrm{~kg} \mathrm{DM} \mathrm{cow}{ }^{-1} \mathrm{~d}^{-1}$ with cows grazing an autumn mixed pasture $(25 \%$ L. perenne $)$. The high herbage intake recorded at the start of this trial $(>9 \mathrm{~kg}$ DM cow ${ }^{-1} \mathrm{~d}^{-1}$ ) could be explained by the report of PérezPrieto et al. (2013), who compared the same pasture allowances above ground level at different herbage masses, registering higher herbage intake and milk production in the high offered herbage mass associated with a higher herbage available fraction product of a greater sward height. During the second half of the trial, there was a decrease in the pre-grazing herbage mass ( $\leq$ $2000 \mathrm{~kg} \mathrm{DM} \mathrm{ha}^{-1}$ ), which is consistent with that reported by Ruiz-Albarrán et al. (2012) for the autumn season in southern Chile.

Pasture for dairy cattle possessing a composition of $18 \%$ to $24 \% \mathrm{DM}, 18 \%$ to $25 \% \mathrm{CP}, 40 \%$ to $50 \% \mathrm{NDF}$

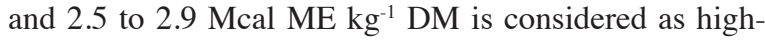
quality pasture (Clark and Kanneganti, 1998). In this study, herbage contents of $\mathrm{CP}$ and ME were high, while DM content was significantly lower (12.7\%), these values correspond to a high quality vegetative forage, compound of tillers and young leaves; however, the high NDF recorded can be explained by the presence of dead material in lower strata of the sward, which is common in autumn (Canseco et al., 2009; Pérez-Prieto et al., 2013). The lower content of NSC would be insufficient for feeding high producing dairy cows (Anrique et al., 2008). Therefore, the recorded values of chemical composition correspond to the characteristics of temperate pastures of southern Chile during autumn (Pulido et al., 2010). Corn silage used had a high content of DM and ME together with a low $\mathrm{pH}$ and $\mathrm{N}-\mathrm{NH}_{3}$ (3.9 and 5.25\%, respectively). Hence it would be considered as of high quality when contrasted with the values of Anrique et al. (2008). The concentrate was formulated with a high energy content and low protein and fiber to complement the autumn herbage.

\section{Food intake, milk production and composition}

The lower intake of corn silage recorded by HCS treatment ( $8 \mathrm{~kg}$ of $9 \mathrm{~kg}$ offered) would be explained by a high substitution rate (close to 1 ) to be a supplementary conserved forage (Phillips, 1988). This decrease in herbage intake per kilogram of supplement food is the main factor that influences the variations in milk yield response to supplementation and is inversely related to milk production (Kellaway and Harrington, 2004). Lower substitution rates $(0.51$ to 0.75$)$ have been reported by Pérez-Prieto et al. (2011) to offer lower pasture allowances and poor quality herbage, which resulted in an increase of total DM intake and milk production, opposite to what has been recorded in this trial.

The LCS treatment presented a slightly superior intake $(0.11 \mathrm{~kg})$ of corn silage than expected due to the variation in the DM content of corn silage offered. A higher herbage intake was reported for LCS and a higher silage intake for HCS, without any differences in total DM intake or energy intake. These results explained the lack of differences of supplementation in milk production or fat or protein yield in milk. Although, milk persistency in both treatments $\left(-0.10 \mathrm{~kg} \mathrm{~d}^{-1}\right)$ was better than that registered for cows receiving only pasture $\left(-0.14 \mathrm{~kg} \mathrm{~d}^{-1}\right)$ (Pulido and Leaver, 2001). Similar situation was reported by Mitani et al. (2005), even though they recorded an increase of total DM intake when offered more corn silage, this did not improve milk production and composition due to the low total CP diet (14.4\%). Moreover, Holden et al. (1995), who offered high pasture availability $\left(14 \mathrm{~kg} \mathrm{cow}^{-1} \mathrm{~d}^{-1}\right)$ and supplemented with $2.3 \mathrm{~kg}$ DM of corn silage, observed a reduction in herbage intake, resulting in similar total DM intake and milk production.

The results of this study can be explained by the reviews of Phillips (1988) and Bargo et al. (2003), who indicate that corn silage supplementation has a positive effect on milk production when offered pasture is restricted; though responses decrease when increased offered pasture and corn silage are included at high level in the diet. Furthermore, only milk solids will increase if total DM intake increases.

Although in this study a low pasture allowance was utilized, LCS treatment (4.5 kg DM cow ${ }^{-1} \mathrm{~d}^{-1}$ ) would have been sufficient to meet the production requirements of the cows, constituting the HCS treatment $(9 \mathrm{~kg}$ DM $\left.\operatorname{cow}^{-1} \mathrm{~d}^{-1}\right)$ an excessive supplementation. Besides the corn silage supplementation allowed decreasing the use of concentrate $\left(3 \mathrm{~kg} \mathrm{cow}^{-1} \mathrm{~d}^{-1}\right)$ compared with the amount of concentrate commonly used under these conditions (1 $\mathrm{kg}$ per $5 \mathrm{~kg}$ milk yield) (Mitani et al., 2005; Pulido et al., 2010).

\section{Live weight and BCS}

The higher weight gain recorded in the LCS treatment would be explained by a reduced mobilization of body reserves, because the HCS treatment tended to have higher BCS at the start of this trial $(2.91 \pm 0.12$ vs. $3.05 \pm 0.3$, respectively). Kellaway and Harrington (2004) indicate 
that cows with elevated BCS are more susceptible to mobilize body reserves and have a restricted intake by hormonal regulation. However, blood metabolites values were adjusted by body condition score as a covariate, registering no significant differences. Therefore, another factor that could explain the higher weight gain observed in the LCS treatment was the higher intake of CP in the total diet in relation to HCS treatment $(18.03 \% v s$. $14.99 \%$, respectively). This is due to a more important participation of the herbage in the LCS diet (48.89\% vs. $27.76 \%$, respectively). A similar situation was reported by Stockdale (1995), who suggested at least $14 \%$ CP in diet of early lactation dairy cows to avoid negative effects on milk production.

Although values of live weight change of HCS were lower than those for LCS treatment, these were suitable for the stage of lactation, presenting the cows even weight and BCS gain in both treatments, reflecting a positive effect of supplementation in cows (Kellaway and Harrington, 2004).

\section{Blood and urine metabolites}

In this experiment, plasma concentrations of $\beta \mathrm{OH}$ butyrate were found above the range of normal values for dairy cows $\left(0.1-0.6 \mathrm{mmol} \mathrm{L}^{-1}\right)$ in both treatments, averaging $1.1 \mathrm{mmol} \mathrm{L}^{-1}$. Similar situation was reported in autumn-grazing dairy cows by Wittwer et al. (2011), who reported values of $1.4 \mathrm{mmol} \mathrm{L}^{-1}$ indicative of subclinical ketosis (Geishauser et al., 1998). However, the high values registered mainly during the last two samplings, regarding the animal performance and the stage of lactation of cows (around $100 \mathrm{~d}$ in milk), would not be consistent with cases of subclinical ketosis and may be associated with the butyrate content in the corn silage; this was not determined, being mainly attributed to the butyric acid produced by ruminal fermentation, which was subsequently metabolized to $\beta \mathrm{OH}$-butyrate and absorbed in the rumen wall (Wittwer et al., 2011). In addition to an expected effect of sampling time, being the largest concentrations of $\beta \mathrm{OH}$-butyrate between 16:00 and 18:00 h ( 2 to $4 \mathrm{~h}$ after peak intake), it would have resulted in a false positive diagnosis of subclinical ketosis (Noro et al., 2011). This was checked by Rothera test, which measured mainly the presence of acetoacetate in urine (positive reaction $>1 \mathrm{mmol} \mathrm{L}^{-1}$ ) (Wittwer, 2012), finding only one cow positive to testing (mild reaction) out of the 14 cows presenting high values, being this reaction indicative of a negative energy balance and not a case of subclinical ketosis (Cucunubo et al., 2013). Otherwise, the increasing of plasma concentrations of $\beta \mathrm{OH}$-butyrate during the last weeks of the trial (Figure 1b) was associated with the lower herbage mass recorded during that period, resulting in a decrease of herbage DM intake and therefore energy intake (Ruiz-Albarrán et al., 2012) and thus increasing the proportion of corn silage consumed in both diets.
The low and similar plasma concentrations of NEFA

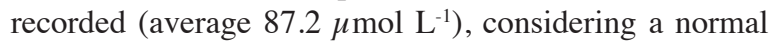
value of $<600 \mu \mathrm{mol} \mathrm{L}^{-1}$, are explained by a positive effect of corn silage supplementation joined to the days in milk of the cows, being in a period where physiologically NEFA concentrations decrease and are stabilized, allowing the assessment of the extent of mobilization in response to diet (Van Knegsel et al., 2007). These values agree with those obtained by Mitani et al. (2005) to supplement with 2 or $4 \mathrm{~kg}$ DM of corn silage to time-restricted grazing dairy cows, without finding differences between treatments and registering NEFA values $<200 \mu \mathrm{mol} \mathrm{L}^{-1}$.

The lower urea plasma concentrations recorded in the HCS treatment were attributed to a better synchrony of energy and $\mathrm{N}$ release in the rumen, due to the input of fermentable carbohydrates of corn silage intake, allowing a better utilization of the herbage protein and ammonia in the rumen, otherwise low urea values could also be associated to lower content of dietary protein (Wittwer, 2000; Noro et al., 2011). However, in both treatments urea concentrations were low (average $4.73 \mathrm{mmol} \mathrm{L}^{-1}$ ), recording values within the reference range during the study (2.6-7.0 mmol L-1), indicating a positive effect of corn silage supplementation (Ruiz-Albarrán et al., 2012).

\section{CONCLUSIONS}

These results suggest by increasing corn silage supplementation from 4.5 to $9 \mathrm{~kg} \mathrm{cow}^{-1} \mathrm{~d}^{-1}$ to autumncalving dairy cows in early lactation grazing low mass pasture, do not modified milk production nor milk fat or milk protein yield, due to a similar total DM and energy intake. The low corn silage supplementation was sufficient to meet the production requirements of the cows and allowed obtaining a better energy balance and greater protein intake; therefore it is recommended for use under these grazing conditions.

\section{ACKNOWLEDGEMENTS}

Research was funded by FONDECYT project 1100513. The support of ANASAC S.A. is gratefully acknowledged for providing the Master's scholarship for Mr. Álvaro Gonzalo Morales Ramírez.

\section{LITERATURE CITED}

AFRC. 1993. Necesidades energéticas y proteicas de los rumiantes. Agricultural and Food Research Council (AFRC). Editorial Acribia, Zaragoza, España.

Anrique, R., R. Fuchslocher, S. Iraira, y R. Saldaña. 2008. Composición de alimentos para el ganado bovino. $3^{\mathrm{a}}$ ed. Consorcio Lechero, Universidad Austral de Chile, Instituto de Investigaciones Agropecuarias, INIA Remehue, Valdivia, Chile.

AOAC. 1996. Official methods of analysis. $16^{\text {th }}$ ed. Association of Official Analytical Chemists (AOAC), Washington DC., USA. AOAC. 2005. Official methods of analysis. $18^{\text {th }}$ ed. Association of Official Analytical Chemists (AOAC), Washington DC., USA. 
Baker, R.D. 1982. Estimating herbage intake from animal performance. p. 77-93. In Leaver, J.D. (ed.) Herbage intake handbook. British Grassland Society, Hurley, UK.

Balocchi, O., R. Pulido, y J. Fernández. 2002. Comportamiento de vacas lecheras en pastoreo con y sin suplementación con concentrado. Agricultura Técnica (Chile) 62:87-98.

Bargo, F., L.D. Muller, E.S. Kolver, and J.E. Delahoy. 2003. Invited review: Production and digestion of supplemented dairy cows on pasture. Journal of Dairy Science 86:1-42.

Bobe, G., J.W. Young, and D.C. Beitz. 2004. Invited review: pathology, etiology, prevention and treatment of fatty liver in dairy cows. Journal of Dairy Science 87:3105-3124.

Boletín Climático. 2012. Boletines climáticos mayo y junio 2012. Departamento de Geofísica, Facultad de Ciencias Físicas y Matemáticas, Universidad de Chile, Santiago, Chile. Available at http://met.dgf.uchile.cl/clima/HTML/BOL_ANT/anterior.htm (accessed September 2013)

Canseco, C., A. Abarzúa, J. Parga, N. Teuber, O. Balocchi, J. Lopetegui, et al. 2009. Calidad nutritiva de las praderas. p. 5167. In Teuber, N., O. Balocchi, and J. Parga (eds.) Manejo del pastoreo. Fundación para la Innovación Agraria (FIA), Santiago, Chile.

Clark, D.A., and V.R. Kanneganti. 1998. Grazing management systems for dairy cattle. p. 311-334. In Cherney, J.H., and D.J.R. Cherney (eds.) Grass for dairy cattle. CABI Publishing, Cambridge, UK.

Cucunubo, L., C. Strieder-Barboza, F. Wittwer, y M. Noro. 2013. Diagnóstico de cetosis subclínica y balance energético en vacas lecheras mediante el uso de muestras de sangre, orina y leche. Revista Científica de la Facultad de Ciencias Veterinarias de la Universidad del Zulia 23:111-119.

Estación Meteorológica UACh. 2013. Facultad de Ciencias de la Ingeniería, Universidad Austral de Chile, Valdivia, Chile. Available at http://clima.inf.uach.cl/ (accessed September 2013).

Ferguson, J.D., D.T. Galligan, and N. Thomsen. 1994. Principal descriptors of body condition score in Holstein cows. Journal of Dairy Science 77:2695-2703.

Garrido, O., y E. Mann. 1981. Composición química, digestibilidad y valor energético de una pradera permanente de pastoreo a través del año. Memoria de título. Universidad Austral de Chile, Facultad de Ciencias Agrarias, Valdivia, Chile.

Geishauser, T., K. Leslie, D. Kelton, and T. Duffield. 1998. Evaluation of five cow side tests for use with milk to detect subclinical ketosis in dairy cows. Journal of Dairy Science 81:438-443.

Goering, H., y P. Van Soest. 1972. Análisis de fibra de forraje. Universidad Agraria La Molina, Lima, Perú.

Hazard, S., M. Morales, N. Butendieck, P. Gómez, y P. Mardones. 2001. Evaluación de la mezcla ensilaje de maíz con ensilaje de trébol rosado en diferentes proporciones, en la alimentación invernal de vacas lecheras en la zona sur. Agricultura Técnica (Chile) 61:306-318.

Holden, L.A., L.D. Muller, T. Lykos, and T.W. Cassidy. 1995. Effect of corn silage supplementation on intake and milk production in cows grazing grass pasture. Journal of Dairy Science 78:154-160.

Kellaway, R., and T. Harrington. 2004. Factors affecting response to supplementation. p. 107-136. In Kellaway, R., and T. Harrington (eds.) Feeding concentrates: supplements for dairy cows. Landlink Press, Victoria, Australia.

Kolver, E.S., and L.D. Muller. 1998. Performance and nutrient intake of high producing Holstein cows consuming pasture or a total mixed ration. Journal of Dairy Science 81:1403-1411.

Mitani, T., M. Takahashi, K. Ueda, H. Nakatsuji, S. Kondo, and M. Okubo. 2005. Effects of supplementary corn silage on the feed intake and milk production of time-restricted grazing dairy cows. Animal Science Journal 76:331-337.

Noro, M., J. Borkert, G.A. Hinostroza, R. Pulido, y F. Wittwer. 2011. Variaciones diarias de metabolitos sanguíneos y su relación con el comportamiento alimenticio en vacas lecheras a pastoreo primaveral. Revista Científica de la Facultad de Ciencias Veterinarias de la Universidad del Zulia 21:125-130
Pérez-Prieto, L.A., J.L.Peyraud, and R. Delagarde. 2011 . Substitution rate and milk yield response to corn silage supplementation of late-lactation dairy cows grazing low-mass pastures at 2 daily allowances in autumn. Journal of Dairy Science 94:3592-3604.

Pérez-Prieto, L.A., J.L. Peyraud, and R. Delagarde. 2013. Does pre-grazing herbage mass really affect herbage intake and milk production of strip-grazing dairy cows? Grass and Forage Science 68:93-109.

Phillips, C.J. 1988. The use of conserved forage as supplement for grazing dairy cows. Grass and Forage Science 43:215-230.

Pulido, R.G., and J.D. Leaver. 2001. Quantifying the influence of sward height, concentrate level and initial milk yield on the milk production and grazing behaviour of continuously stocked dairy cows. Grass and Forage Science 56:57-67.

Pulido, R.G., R. Muñoz, C. Jara, O.A. Balocchi, J.P. Smulders, F. Wittwer, et al. 2010. The effect of pasture allowance and concentrate supplementation type on milk production performance and dry matter intake of autumn-calving dairy cows in early lactation. Livestock Science 132:119-125.

Ruiz-Albarrán, M., O.A. Balocchi, M. Noro, F. Wittwer, and R.G Pulido. 2012. Effect of increasing pasture allowance and grass silage on animal performance, grazing behavior and rumen fermentation parameters of dairy cows in early lactation during autumn. Livestock Science 150:407-413.

Ruiz-Albarrán, M., M. Noro, O. Balocchi, F. Wittwer, y R.G. Pulido. 2011. Desempeño productivo de vacas al inicio de lactancia pastoreando dos ofertas de pradera y suplementadas con ensilaje de pradera o maíz. Abstract 121-122. In Resúmenes del XXXVI Congreso de la Sociedad Chilena de Producción Animal (SOCHIPA), Punta Arenas. 9-11 November. SOCHIPA, Santiago, Chile.

Schöbitz, J., M. Ruiz-Albarrán, O.A. Balocchi, F. Wittwer, M. Noro, and R.G. Pulido. 2013. Effect of increasing pasture allowance and concentrate supplementation on animal performance and microbial protein synthesis in dairy cows. Archivos de Medicina Veterinaria 45:247-258

Soil Survey Staff. 1992. Keys to soil taxonomy. $5^{\text {th }}$ ed. Pocahontas Press, Blackburg, Virginia, USA

Sotelo, J., M. Noro, F. Wittwer, J.P. Smulders, y R.G. Pulido. 2012 Evaluación de la oferta de pradera y tipo de concentrado sobre algunos parámetros ruminales en vacas lecheras en pastoreo otoñal. Archivos de MedicinaVeterinaria 44:167-172.

Stockdale, C.R. 1995. Maize silage as a supplement for pasturefed dairy cows in early and late lactation. Australian Journal of Experimental Agriculture 35:19-26.

Tilley, J.M.A., and R.A. Terry. 1963. A two stage technique for in vitro digestion of forage crops. Journal of the British Grassland Society 18:104-111.

Van Knegsel, A.T.M., H. Van den Brand, E.A.M. Graat, J. Dijkstra, R. Jorritsma, E. Decuypere, et al. 2007. Dietary energy source in dairy cows in early lactation: metabolites and metabolic hormones. Journal of Dairy Science 90:1477-1485.

Van Soest, P.J., J. Robertson, and B. Lewis. 1991. Methods for dietary fiber, neutral detergent fiber, and nonstarch polysaccharides in relation to animal nutrition. Journal of Dairy Science 74:35833595.

Wittwer, F. 2000. Diagnóstico dos desequilíbrios metabólicos de energía em rebanhos bovinos. In Gonzalez, F., J. Barcellos, H. Ospina and L. Ribeiro (eds.) Perfil metabólico em ruminantes: seu uso em nutrição e doenças nutricionais. Universidade Federal Do Río Grande Do Sul, Porto Alegre, Brasil.

Wittwer, F. 2012. Manual de patología clínica veterinaria. $2^{\mathrm{a}}$ ed Universidad Austral de Chile, Valdivia, Chile.

Wittwer, F., M. Noro, O. Balocchi, M. Ruiz-Albarrán, y R. Pulido. 2011. Respuesta metabólica de vacas en lactancia tardía alimentadas con dos ofertas de pradera y tipos de ensilajes. Abstract 55-56. In Resúmenes del XXXVI Congreso de la Sociedad Chilena de Producción Animal (SOCHIPA), Punta Arenas. 9-11 November. SOCHIPA, Santiago, Chile. 